\title{
The medical center preference of patients with head and neck cancer and factors that affect this preference
}

\author{
๑Tuğçe Şimşek ${ }^{1}$, ĐYusuf Özgür Biçer ${ }^{2}$, DSerap Köybaşı Sanal ${ }^{3}$ \\ ${ }^{1}$ Amasya University Sabuncuoglu Serefeddin Training and Research Hospital, Department of Otorhinolaryngology and Head and Neck Surgery, \\ Amasya, Turkey \\ ${ }^{2}$ Abant Izzet Baysal University Izzet Baysal Training and Research Hospital, Department of Otorhinolaryngology and Head and Neck Surgery, \\ Bolu, Turkey \\ ${ }^{3}$ Private Galen University, Medical Faculty, Tinaztepe Hospital, Department of Otorhinolaryngology and Head and Neck Surgery, İzmir, Turkey.
}

Cite this article as: Şimşek T, Biçer YÖ, Köybaşı Sanal S. The medical center preference of patients with head and neck cancer and factors that affect this preference. Anatolian Curr Med J 2021; 3(1): 5-9.

\begin{abstract}
Aim: Nowadays, cancer is one of the most important health problems due to its high mortality and morbidity as well as its cost, duration, and side effects. In some countries, the treatment and management of cancer-diagnosed patients are performed in a center. The aim of this study is to determine the centers preferred for treatment of patients with head and neck cancer and to investigate the factors responsible for that preference.

Material and Method: The database was scanned, and the patients diagnosed with head and neck cancer were determined. A telephone questionnaire was performed with each participant.

Results: There was a statistically significant difference between the center of diagnosis and the center of treatment $(\mathrm{p}<0.001)$. A statistically significant difference was found between the center of treatment and treatment methods $(\mathrm{p}<0.001)$.

Conclusions: Factors influencing patients' hospital choice and their experience in service utilization process include the environment where the service is provided, availability of modern machinery and equipment, and other physical conditions. Administering treatment within the city of residence will benefit patients in terms of psychological secondary gains.
\end{abstract}

Keywords: Head and neck cancer, surgery, chemoradiotherapy, health public, psychosocial impact

\section{INTRODUCTION}

Nowadays, cancer is one of the most important health problems due to its high mortality and morbidity as well as its cost, duration, and side effects (1). Although its rank among causes of death, there is no reliable information about the incidence of the disease. Although the differences in the results of the studies reported from various centers reveal the epidemiological dimension of cancer, it should be kept in mind that while some clinics and units of some centers leads to improved patient flow, some clinics and units do not affect statistical results (2).

Although the incidences and mortality rates of head and neck cancers are low among other cancers, they have an important place due to their anatomical, functional, and cosmetic properties (3). Head and neck cancers constitute approximately $3 \%$ of all cancers in the United
States (4). These cancers, which affect both genders, are seen twice more commonly in males than females (5). In United States of America (USA), the treatment and management of cancer-diagnosed patients are performed in a center. There are few multidisciplinary centers and cancer surgery is seldom performed in the periphery of a city (6).

We believe that the volume of cancer surgery in university hospitals of relatively small provinces is not proportional with the current cancer incidence. It is observed that the patients are directed to larger centers for various reasons. These reasons may be related to the surgeon, hospital, or patient. The aim of this study was to investigate the factors that affect the selection of treatment centers. So, we purposed to determine the centers preferred for treatment of patients with head and 
neck cancer and to investigate the factors responsible for that preference in Abant Izzet Baysal University Medical Faculty Hospital, Department of Otolaryngology\&Head and Neck Surgery.

\section{MATERIAL AND METHOD}

Abant Izzet Baysal University Medical Faculty database was scanned, and the patients diagnosed with head and neck cancer in the Department of Otolaryngology\&Head and Neck Surgery between 2006-2014 were determined. Ethics Committee Approval was also obtained from Amasya University Clinical Researches Ethics Committee (Date: 08/11/2019, Number: E.29795). The data of 127 patients were accessed. Patients' phone numbers were retrieved from the hospital registry system and a telephone questionnaire was performed with each participant. However, 96 (75.6\%) of 127 patients could be reached. The patients were first asked about their demographic properties which included age, occupation, place of residence, educational level, and monthly income recorded. The place of residence was divided into three groups as city center, towns, and villages.

Educational level was classified as non-literate, illiterate, primary-secondary graduate, high school graduate, and university. Monthly income was classified as $<1000$ $\mathrm{TL}, 1000-2000 \mathrm{TL}, \geq 2000 \mathrm{TL}$. Then, in the survey the patients were asked about their preference for the place of treatment and its reasons. The patients' place of diagnosis was classified as Bolu or other cities; department of diagnosis as oto-rhino-laryngology (ORL) or other; place of treatment as Bolu, other than Bolu (voluntarily), and other than Bolu (for various reasons). Additionally, the modality of treatment was classified as surgery, surgery+chemoradiotherapy, chemotherapy only, radiotherapy only, chemoradiotherapy only and other. Receiving treatment at another center was categorized as the patient's own preference, physician's referral, and hospital-driven reasons; the reason for their choice of another center as the physician's preference, choice of the physician at the external center, choosing no other center in Bolu, and choosing an external center.

\section{Statistical Analysis}

SPSS software (version 21.0 for Windows, IBM Corp., Armonk, NY, USA) was used for all data analyses. Descriptive statistics are shown as mean, standard deviation, median, minimum value, maximum value, and interquartile range for numerical variables. Categorical variables were reported as numbers and percentages. Chi-square and Fisher's Exact Test were used to compare categoric variables. Bonferroni-Holm correction was applied in post-hoc analyzes. The significance level was set to $\mathrm{p}<0.05$ for all statistical comparisons.

\section{RESULTS}

Of the 127 patients diagnosed with cancer, 96 patients were reached. The mean age of the patients was 60.09 years (range: 8 and 88) (Table 1). Seventy-two patients were male and 24 were female. Twenty patients died for various reasons, and 76 were alive. Among occupational statuses, the retired worker group had the highest proportion $(\mathrm{n}=20)$ while housewifery was the second most common occupation $(n=17)$. An analysis of education level was revealed that first-middle school graduates had the highest rate $(n=66)$. The monthly income of fifty-three patients was $\leq 1000$ TL. Fifty-six patients were residing in the city center, 13 in a town, and 27 in a village (Table 2).

\begin{tabular}{|c|c|c|}
\hline Mean & & 60.09 \\
\hline \multirow{6}{*}{$\begin{array}{l}\text { The statistics } \\
\text { of age }\end{array}$} & Median & 62.00 \\
\hline & Std. Deviation & 15.396 \\
\hline & Minimum & 8 \\
\hline & Maximum & 88 \\
\hline & Interquartile Range & 17 \\
\hline & Mean & 60.09 \\
\hline
\end{tabular}

\begin{tabular}{|c|c|c|c|}
\hline \multicolumn{2}{|c|}{ Demographic Features } & Frequency & Percent \\
\hline \multirow{2}{*}{ Gender } & Male & 72 & 75 \\
\hline & Female & 24 & 25 \\
\hline \multirow{9}{*}{ Occupation } & Officer & 6 & 6.3 \\
\hline & Worker & 14 & 14.6 \\
\hline & Unemployed & 10 & 10.4 \\
\hline & Housewife & 17 & 17.7 \\
\hline & Retired officer & 8 & 8.3 \\
\hline & Retired worker & 20 & 20.8 \\
\hline & Farmer & 11 & 11.5 \\
\hline & Self-employment & 7 & 7.3 \\
\hline & Student & 3 & 3.1 \\
\hline \multirow{5}{*}{$\begin{array}{l}\text { Education } \\
\text { level }\end{array}$} & No literate & 2 & 2.1 \\
\hline & Literate & 6 & 6.3 \\
\hline & Primary- secondary school & 66 & 68.8 \\
\hline & High school & 12 & 12.5 \\
\hline & University & 10 & 10.4 \\
\hline \multirow{4}{*}{$\begin{array}{l}\text { Monthly } \\
\text { income }\end{array}$} & No & 19 & 19.8 \\
\hline & $<1000$ & 53 & 55.2 \\
\hline & $1000-2000$ & 17 & 17.7 \\
\hline & $\geq 2000$ & 7 & 7.3 \\
\hline \multirow{2}{*}{ Residence } & City center & 56 & 58.3 \\
\hline & Town & 13 & 13.5 \\
\hline
\end{tabular}

Ninety-one $(94.8 \%)$ of 96 patients were diagnosed by ORL clinics and $5(5.2 \%)$ patients were diagnosed by other clinics. Eighty-one (84.4\%) patients were diagnosed in Bolu and $15(15.6 \%)$ patients were 
diagnosed outside Bolu. Malignant neoplasm of larynx was the most commonly diagnosed malignant neoplasm $(\mathrm{n}=42 ; 43.8 \%)$. Thirty-six (37.5\%) of 96 patients did not undergo surgery but received an alternative treatment. One (1\%) patient refused treatment. Thirty-six (37.5\%) patients were treated in Bolu. An analysis of external center preference among patients treated at an external center revealed that $47(48.9 \%)$ patients preferred an external center due to absence of a relevant department and insufficient equipment while 12 patients were administered treatment at an external center upon their own request. Patients were referred for non-surgical treatment because of the lack of a department, and a medical oncologist and radiation oncologist. An analysis of patients treated by an external center upon their own request showed that 8 patients chose to receive treatment at an external center due to their preference of the external center hospital while 4 patients preferred an external center because of the preference of the physician.

Eighty-one patients were diagnosed in Bolu, and 34 (42.5\%) patients completed their treatment in Bolu. One patient refused treatment. Out of 80 patients, 41 (51.2\%) were referred to an external center for various reasons. Only $5(6.17 \%)$ patients received treatment by their own request. Fifteen patients were diagnosed at an external center, of whom 7 (46.6\%) were referred to an external center by their own request 6 (40\%) for various reasons, while $2(13.3 \%)$ patients were treated in Bolu. There was a statistically significant difference between the center of diagnosis and the center of treatment $(\mathrm{p}<0.001)$. A post-hoc analysis, showed that the statistical difference between the groups stemmed from the group treated outside Bolu upon their own request. So, as the rate of diagnosis at an external center increased, the rate of preferring an external center upon patient's request also increased.

An analysis of the place of treatment and the method of treatment revealed that 34 of 36 patients treated in Bolu were treated with surgery only and 2 with a combination of surgery and chemotherapy. Among patients referred to an external center because of various reasons, four patients underwent surgery, while 43 patients underwent chemotherapy, radiotherapy, or chemoradiotherapy irrespective of undergoing surgical treatment. Among patients treated at an external center upon their own request, 6 underwent surgery only and 6 underwent chemotherapy, radiotherapy, or chemoradiotherapy, irrespective of undergoing surgery. According to these results, a statistically significant difference was found between the place of treatment and the method of treatment $(\mathrm{p}<0.001)$. In the post-hoc analysis, 3 groups were responsible for this significant difference, and 3 groups were significantly different from one another. (Table 3)

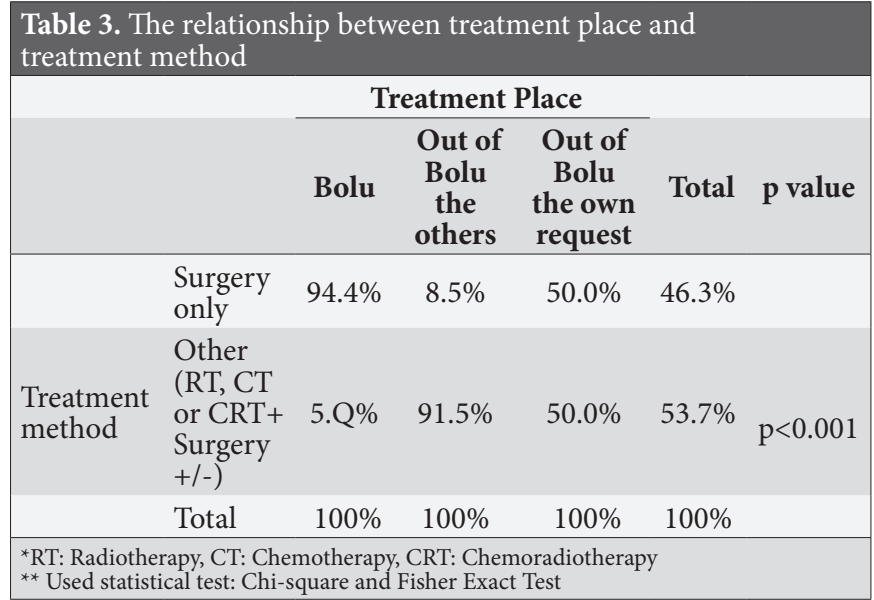

\section{DISCUSSION}

Most of the patients included in our study were diagnosed in Bolu, and most of the patients diagnosed in Bolu were also treated in Bolu. Most of the patients who were diagnosed at an external center preferred to be treated at an external center. These results were statistically significant $(\mathrm{p}<0.005)$. This suggests that the first dialogue with the patient at the time of diagnosis is a primary determinant of patients' preferences. Our results suggest that hospital conditions are only secondarily effective after a patient's trust in his/her doctor.

In the past, it is seen that the patient made the choice between the alternatives that the patient participated in the selection process and decided together with the physician or the physician offered them. They even decide on the choice of health institutions for some nonserious illnesses and health check-ups (7).

It was determined that hospital services should be easily accessible. This is particularly important in the selection of emergency services and general hospital services. Therefore, proximity to the patients and transportation facilities should be considered in the selection of hospital establishment (8).

Another factor affecting a patient's decision to choose the hospital and the experience of benefiting process from the service is the environment in which the service is provided (examination room, patient rooms, cleanliness and comfort of waiting rooms), having modern machinery-equipment, and the qualification of other physical conditions (appearance of the building, elevators, parking lots etc.). Therefore, hospital managers should improve their physical conditions to improve patient satisfaction and closely keep up with medical technological developments. For centers that provide specific services (e.g., cardiovascular surgery centers, cardiology, and brain surgery units etc.), employing well-known experts is an important factor in addition to having advanced technological devices for affecting patients' hospital choices (7). 
With aging, there is a serious decline in the rate of preference given to public hospitals. It is thought that the main factor in this occurrence is long waiting periods due to heavy agglomeration in public hospitals. Again, according to our study results, one of the most important factors affecting individuals' health institution choices in our country is the availability of transport at facilities to an institution (9). Individuals living in rural areas, present to primary and secondary health institutions instead of universities and private hospitals because they have limited resources for transportation to the latter. A higher level of income allows individuals to prefer universities and private hospitals, while low-income individuals prefer first- and second-level health institutions (9).

In our study, there was no significant difference between the patients' occupational status and their hospital preference; the level of income and hospital preference; the place of residence and hospital preferences; and patient age and hospital preference $(\mathrm{p}>0.005)$.

Measuring and improving the quality of services offered by hospitals operating in today's rapidly transforming and increasingly competitive health sector has become an important necessity. Measuring and evaluating the perceived quality of service in health facilities will also contribute significantly to the efficient use of the limited resources of public hospitals; by this way, it would be possible to cut costs, to achieve competitive advantage, and to meet or even exceed patient expectations. In the light of the theoretical and empirical research findings reported so far, the following evaluations can be made. Research on quality of service reveals that service quality is related to company performance, customer satisfaction, and purchasing power $(10,11)$.

A patient's perception of service quality has a key role in the success of a health institution, mainly through patient satisfaction its impact on hospital profitability. However; the impact of perceived service quality on service providers' success or failure has been demonstrated by various studies (12).

In our study, 12 patients preferred to receive treatment at an external center. Eight of these patients chose a hospital-based external center.

Zerenler et al. (13) investigated the reasons of hospital preference in a study of a total of 374 patients, four of whom were public. They observed that the most important factor affecting health institution preference was a hospital's agreement with the social security institution. It can be said that the criterion of social security institution agreement has a negative impact on this competitive understanding when it is taken into consideration that the private health institutions, which increase the number of social security institutions, increase the competition significantly (13).
It was determined that patients needed patient-centered and basic health system based service. Therefore, it is necessary to investigate new approaches that provide potentially more meaningful results and better cost effectiveness (14).

In a study carried out by Önsüz et al. (15) on 135 patients in the Faculty of Medicine of Marmara University, social security and referral facilities were the leading causes of hospitalization. In another study, the authors from Haseki Education and Research Hospital polyclinics conducted a study on 550 patients in the hospital and reported that the major reason for the preference of this hospital was the trust in physicians, with that effect having been followed by the effectiveness of the patient appointment system (16).

In our study, most of the patients who were referred to an external center for various reasons needed additional non-surgical treatment, and most of the patients were referred to the external center because the institution of diagnosis did not have any relevant department. This shows the necessity of supporting the establishment of the departments that complement the multidisciplinary approach in the hospitals in relatively small provinces. In addition, administering treatment in the city of residence will provide patients with psychological secondary gains.

\section{CONCLUSION}

Cancer treatment and follow-up centers such as cancer screening and early diagnosis centers should be established in order to enable individuals struggling with cancer in the society to access the service easily. Within the scope of cancer diagnosis and treatment center, systemic algorithms should be created in which patients can receive psychological support and the patient can easily access the service. This problem is not only an issue for an individual with cancer. This is a community problem and it can be possible to increase the level of community welfare by creating permanent systematic solutions.

\section{ETHICAL DECLARATIONS}

Ethics Committee Approval: The study was also obtained from Amasya University Clinical Researches Ethics Committee (Date: 08/11/2019- Number: E.29795).

Informed Consent: Because the study was designed retrospectively, no written informed consent form was obtained from patients.

Referee Evaluation Process: Externally peer-reviewed.

Conflict of Interest Statement: The authors have no conflicts of interest to declare. 
Financial Disclosure: The authors declared that this study has received no financial support.

Author Contributions: All of the authors declare that they have all participated in the design, execution, and analysis of the paper, and that they have approved the final version.

\section{REFERENCES}

1. Parkin DM, Bray, F, Ferlay, J, Pisani P. Global cancer statistics, 2002. CA: Cancer J Clinicians 2005; 55: 74-108.

2. İzmirli M, Altın S, Dernek BO, Ünsal M. SSK Okmeydanı Eğitim ve Araştırma Hastanesi Onkoloji Merkezi'nin 1999-2004 yılları kanser istatistikleri. [Article in Turkish] Türk Onkoloji Derg 2007; 22: 172-82

3. Yılmaz M, Yılmaz YZ. Baş-boyun kanserlerinin etiyolojisi ve epidemiyolojisi [article in Turkish] Kanser Gündemi Derg 2013; 1: 9-14.

4. Jemal A, Siegel R, Xu J, Ward E. Cancer statistics, 2010. CA: Cancer J Clinicians 2010; 60: 277-300.

5. Tarver T. Cancer Facts\&Figures 2012. American Cancer Society (ACS). J Consumer Health On the Internet 2012; 16: 366-7.

6. T.C. Sağlık Bakanlığı Kanserle Savaş Daire Başkanlığı Türkiye’de Kanser Kontrolü. [Article in Turkish] Ankara: 2009; 257-8.

7. Tengilimoğlu D. Hastane seçimine etkili olan faktörler: Bir alan uygulaması. [Article in Turkish] Gazi Universitesi Iktisadi ve Idari Bilimler Fakultesi Derg 2001; 3: 1.

8. Boscarino J, Stelber SR. Hospital shopping and consumer choice. J Health Care Marketing 1982; 2: 2.

9. Özkoç H. Hastaların Sağlık Kurumu Tercihlerini Etkileyen Faktörlerin Belirlenmesi: Uygunluk Analizi Ve Nested Logit Model. [Article in Turkish] Dokuz Eylül Üniversitesi Sosyal Bilimler Enstitüsü Derg 2013; 15: 267-80.

10. Bitner MJ, Booms BH, Tetreault MS. The service encounter: diagnosing favorable and unfavorable incidents. J Marketing 1990; 54: 71-84.

11. Parasuraman A, Zeithaml VA, Berry LL. A conceptual model of service quality and its implications for future research. J Marketing 1985; 49: 41-50.

12. Bolton RN, Drew JH. A multistage model of customers' assessments of service quality and value. J Consumer Res $1991 ; 17: 375-84$.

13. Zerenler M, Ögüt A. Sağlık sektöründe algılanan hizmet kalitesive hastane tercih nedenleri araştırması: Konya örneği. [Article in Turkish] Selçuk Üniversitesi Sosyal Bilimler Enstitüsü Derg 2007; 18: 501-19.

14. Schöpf AC, Vach W, Jakob M, Saxer F. Routine patient surveys: Patients' preferences and information gained by healthcare providers. PloS one 2019; 14: 8 .

15. Önsüz M, Topuzoğlu A, Cöbek U, Ertürk S, Y1lmaz F, Birol S. İstanbul'da Bir Tıp Fakültesi Hastanesinde Yatan Hastaların Memnuniyet Düzeyi. [Article in Turkish] Marmara Med J 2008; 21: 33-49.

16. Yıldırım YS, Aksoy F, Veyseller B, Altın S. Hastaların hastane tercihini etkileyen faktörler. [Article in Turkish] Haseki Tip Bült 2009; 47: 11-6. 